\title{
A STUDY ON OXIDATION TREATMENT OF URANIUM METAL CHIP UNDER CONTROLLING ATMOSPHERE FOR SAFE STORAGE
}

\author{
CHANG-KYU KIM*, CHUL-GOO JI, SANG-OH BAE, YOON-MYEOUNG WOO, JONG-GOO KIM and YEONG- \\ KEONG HA
}

Korea Atomic Energy Research Institute

150, Deokjin-Dong, Yuseong-Gu, Daejeon, 305-353, Korea

${ }^{*}$ Corresponding author. E-mail : Ckkim2@kaeri.re.kr

Received August 16, 2010

Accepted for Publication March 14, 2011

The U metal chips generated in developing nuclear fuel and a gamma radioisotope shield have been stored under immersion of water in KAERI. When the water of the storing vessels vaporizes or drains due to unexpected leaking, the U metal chips are able to open to air. A new oxidation treatment process was raised for a long time safe storage with concepts of drying under vacuum, evaporating the containing water and organic material with elevating temperature, and oxidizing the uranium metal chips at an appropriate high temperature under conditions of controlling the feeding rate of oxygen gas. In order to optimize the oxidation process the uranium metal chips were completely dried at higher temperature than $300{ }^{\circ} \mathrm{C}$ and tested for oxidation at various temperatures, which are $300{ }^{\circ} \mathrm{C}, 400^{\circ} \mathrm{C}$, and $500{ }^{\circ} \mathrm{C}$. When the oxidation temperature was $400{ }^{\circ} \mathrm{C}$, the oxidized sample for 7 hours showed a temperature rise of $60{ }^{\circ} \mathrm{C}$ in the self-ignition test. But the oxidized sample for 14 hours revealed a slight temperature rise of $7^{\circ} \mathrm{C}$ representing a stable behavior in the self-ignition test. When the temperature was $500{ }^{\circ} \mathrm{C}$, the shorter oxidation for 7 hours appeared to be enough because the self-ignition test represented no temperature rise. By using several chemical analyses such as carbon content determination, X-ray deflection (XRD), Infrared spectra (IR) and Thermal gravimetric analysis (TGA) on the oxidation treated samples, the results of self-ignition test of new oxidation treatment process for $\mathrm{U}$ metal chip were interpreted and supported.

KEYWORDS : U Metal Chip, Storage, Oxidation, Atmosphere Control, Self-ignition Test, Chemical Analysis, Carbon Content Analysis, XRD Diffraction, TGA, Infra-red Spectra, Acceptable Condition

\section{INTRODUCTION}

At KAERI, depleted uranium metal has long been used as a surrogate material for nuclear metallic fuel development as well as a raw material for gamma radioactive ray shields. Whenever a uranium metal ingot is cut into pieces or machined, uranium metal chips are automatically generated. In general, uranium metal in large pieces is not pyrophoric at room temperature [1]. However, uranium chips are liable to ignite due to their large specific surface area. Reportedly, uranium metal powder of about $10 \mathrm{~mm}$ size can ignite at lower than $100{ }^{\circ} \mathrm{C}$ [2]. Oxidation of a uranium metal surface forms a uranium oxide film and then proceeds further by penetration of oxygen through the film. The oxidation rate increases exponentially with temperature but actually is controlled by the penetration rate of oxygen. When the oxidation layer is thick or the temperature is relatively high, the oxide layer is exfoliated from unsound and weak areas.
The reaction rate fluctuates according to the exfoliation rate. In general, as the temperature increases the oxidation rate gets higher. When the temperature is higher than 625 ${ }^{\circ} \mathrm{C}$, the oxidation film spalls off with powder and it accelerates the oxidation rate [3]. When uranium metal is stored at $100 \%$ relative humidity in normal air, it has been reported that the corrosion rate is greater than that in dry air or less than $90 \%$ relative humidity air by approximately an order of magnitude [4]. When a uranium chip is wetted with water, it becomes more ignitable as a result of uranium hydride, which is a reaction product of uranium metal and water, as shown in the following reactions [5].

$$
\begin{aligned}
& \mathrm{U}+\mathrm{O}_{2} \rightarrow \mathrm{UO}_{2}+\triangle \mathrm{Q} \\
& \mathrm{U}+2 \mathrm{H}_{2} \mathrm{O} \rightarrow \mathrm{UO}_{2}+2 \mathrm{H}_{2}+\triangle \mathrm{Q} \\
& \mathrm{U}+3 / 2 \mathrm{H}_{2} \rightarrow \mathrm{UH}_{3}+{ }^{\circ}, \mathrm{Q} \\
& 4 \mathrm{UH}_{3}+7 \mathrm{O}_{2} \rightarrow 4 \mathrm{UO}_{2}+6 \mathrm{H}_{2} \mathrm{O}+\triangle \mathrm{Q}
\end{aligned}
$$

Accordingly the safe storage of the above uranium chip would necessitate a sort of inert atmosphere or a 
passivation measure on the surface of the uranium chip. In some cases, an immersion method in mineral oil has been applied because oil can prevent a uranium chip from contacting air or water. It is known that the $\mathrm{Y}-12$ plant in the USA has used a water immersion method without any problems [6]. Presumably the reaction rate is very strongly dependant on temperature, so that enough water can keep uranium chips at low temperature. At KAERI, all kinds of uranium chips have been stored by the immersion in water.

It is thought that one measure for perfect safe storage could be an oxidation treatment of uranium chips, which is a kind of stabilization treatment. In general, uranium chips ignite in the air and then vigorously burn generating flames and smoke containing dust induced from the contaminated organic inclusions. For collecting the dust and preventing the contamination of the environment, a lot of work as well as some complex equipment are required. In order to avoid this difficulty, steady oxidation under a controlling atmosphere has been considered. At KAERI, uranium scraps of chip shape are stored under water. The concept of the new steady oxidation process consists of evacuating the oxidation chamber, evaporating the containing water and organic material by elevating the temperature, and oxidizing the uranium chip at an appropriate high temperature while controlling the feeding rate of oxygen gas. New equipment was designed on the basis of the above concept and manufactured by local industry. In order to optimize the oxidation process parameters, some oxidation tests for a uranium chip were done for various temperatures and holding times. The oxidized product of the uranium chip was analyzed and assessed in the safe storage.

\section{EXPERIMENTS}

\subsection{Sampling U Chips for Experiments}

A chip from cutting a uranium metal ingot by bandsaw is observed to be plate-like and longish as in Fig.1. The chip size has been measured to be between 200 to

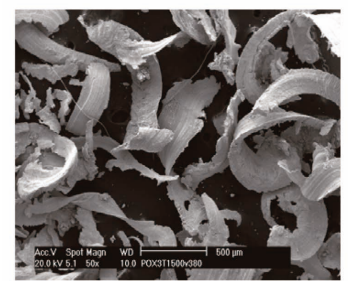

(a)

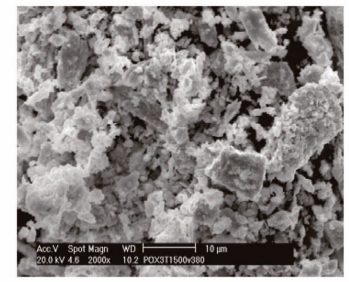

(b)
Fig. 1. Morphologies of Uranium Chips: (a) Chips Generated from Cutting a Uranium Metal Ingot by Band-saw and (b) Chips under a Long-time Storage in Water
$400 \mu \mathrm{m}$. When a uranium chip is stored by immersion in water, it reacts with water and then becomes porous.

A chip from machining uranium metal parts by lathe, which is called as turnings, is very long. The chip size from machining by a lathe is generally larger than that from band-sawing. The portion of band-saw chips is more than $50 \%$ of the total uranium chips under storage at KAERI. Because band-saw chips have more risk for ignition, oxidation treatment for them is under way as a priority. Samples for this study were taken from bandsaw chips immersed in water.

\subsection{Oxidation Experiments}

The oxidation experiments for the uranium chips were performed using newly designed and manufactured equipment, which is able to control the atmosphere available for vacuum and oxygen and the temperature up to $500{ }^{\circ} \mathrm{C}$. The temperatures of the oxidation treatments were performed at $300^{\circ} \mathrm{C}, 400{ }^{\circ} \mathrm{C}$, and $500{ }^{\circ} \mathrm{C}$. When the chips immersed in water in a plastic barrel are taken, they seem like a sludge containing water. Accordingly, before oxidation treatment, the sludge-like chips were dried by evacuating the air in the oxidation chamber and elevating the temperature up to oxidation temperature condition for 7 hours. The chip was charged in a rotating drum located in the oxidation chamber. There are some baffles on the inside wall of the drum. The charged sludge-like chips was jumbled so that oxygen contact with them became more efficient. After the water contained in the sludgelike chips was removed, the oxidation chamber was heated up to the intended temperature after evacuating the chamber and then oxygen gas was fed with a slowrate up to 650 torr. And then this oxidation condition was maintained for 7 hours in one day. Oxygen gas was put in the almost completely cooled oxidation chamber for a kind of self-ignition test of the uranium chips while checking the temperature of the chamber. One additional oxidation treatment, in which the oxidation time at the elevated temperature was 7 hours, was done in order to stabilize the uranium chips more completely. A selfignition test was done in the above way to check the stability of the uranium chips with a viewpoint of safe storage.

\subsection{Chemical Analysis for Various Oxidized Samples of $U$ Chips}

After each step of oxidation treatment, a sample was taken from the uranium chips under processing. Some chemical analyses were performed for the samples. The content of uranium and carbon in the samples was measured individually by Induced Coupled Plasma Atomic Emission Spectroscopy (ICP-AES, Jobin Yvon ULTIMA 2C) and a Carbon analyzer (ELTRA CS800). An X-ray diffraction analysis was carried out for the oxidized samples. 


\subsection{Thermo-gravimetric Analysis}

Firstly, the weight losses were measured in an inert Ar gas flow at $1 \mathrm{~atm}$. and temperatures ranging from $20^{\circ} \mathrm{C}$ to $600{ }^{\circ} \mathrm{C}$ with a heating rate of $1{ }^{\circ} \mathrm{C} / \mathrm{min}$ using a Setaram TGA-92 thermo-analyzer. And then the samples were repeatedly heat-treated in an air atmosphere in the same way as above. The weight gains from oxygen during heat-treatment were measured and then compared with the weight of the samples previously heat-treated under the Argon atmosphere.

\subsection{Identification of the Chemical Structure in the Heat-treated Samples Using Infrared Spectra}

Infrared spectroscopy provides information on the chemical bonding character of compounds and so it can be used for the identification of the chemical structure of a complex U-O system. The sample \#4 among 10 samples was chosen for FTIR measurement, because it was in a well dried state when treated at a relatively low temperature, $300{ }^{\circ} \mathrm{C}$, which is not high enough to burn all organic compounds. So organic compounds contained in the sample could be identified from the Infrared spectra. In order to identify the chemical structure in the sample, the sample was heat-treated in several ways, at $420{ }^{\circ} \mathrm{C}$ and $650{ }^{\circ} \mathrm{C}$ in air, as well as $650{ }^{\circ} \mathrm{C}$ in argon. The infrared spectra were measured in the range of 4000 to $400 \mathrm{~cm}^{-1}$ at room temperature.

\section{OXIDATION RESULT}

\subsection{Oxidation at $300^{\circ} \mathrm{C}$}

Sludge-like uranium chips of $15.56 \mathrm{~kg}$ were charged in the oxidation chamber. The chamber was evacuated up to about 40 torr and then heated up to $100^{\circ} \mathrm{C}$ for one hour. This drying treatment was done for 7 hours. A self-ignition test was conducted for the drying-treated uranium chips, which were cooled to almost room temperature. With no change in the chamber temperature no self-ignition was assumed to happen. After disassembling the chamber the drum containing the chips was weight-measured. The weight change was $2.36 \mathrm{~kg}$. The portion of weight loss for total charging weight was about $15 \%$. It is thought that this drying condition would not be enough to remove the water in the sludge-like U chips completely.

The uranium chips, which were dried at $100^{\circ} \mathrm{C}$ under evacuation, were further dried at $300{ }^{\circ} \mathrm{C}$ under evacuation. It took about 1.5 hours to elevate temperature up to $300^{\circ} \mathrm{C}$. This drying treatment was done for 6.5 hours. A selfignition test was performed while feeding oxygen gas with $7.0 \mathrm{ml} / \mathrm{min}$ and measuring the drum temperature. The oxygen pressure in the chamber was controlled between 550 to 650 torr. The temperature rose from $11^{\circ} \mathrm{C}$ to $65^{\circ} \mathrm{C}$ gradually over 75 minutes from the presumed oxidation reaction as shown in Fig. 2. The oxygen pressure increased to maximum pressure for about 15 minutes.

The oxidation reaction rate was assumed to be much slower than the expected rate. The reason could be attributed to insufficient contact of the chips with oxygen or to the barrier of the oxidized layer of the chip surface. The weight of the uranium chip decreased to $12.42 \mathrm{~kg}$ when drying at $300{ }^{\circ} \mathrm{C}$. The loss portion of weight from the original charging weight was about $20.2 \%$. After drying the sludge-like uranium chips at $300{ }^{\circ} \mathrm{C}$ it was visually observed to be powder-like without any stickiness.

After a self-ignition test, the chips were heated to 300 ${ }^{\circ} \mathrm{C}$ for one hour in an oxygen atmosphere of about 600 torr and the oxidation condition was maintained for 7 hours. After cooling to room temperature, a self-ignition test was performed in the above way. The temperature increased more slowly than it did for the chip dried at $300{ }^{\circ} \mathrm{C}$ from $8^{\circ} \mathrm{C}$ to the maximum temperature of $18^{\circ} \mathrm{C}$ over about 75 minutes as in Fig. 2. The weight of the remaining uranium

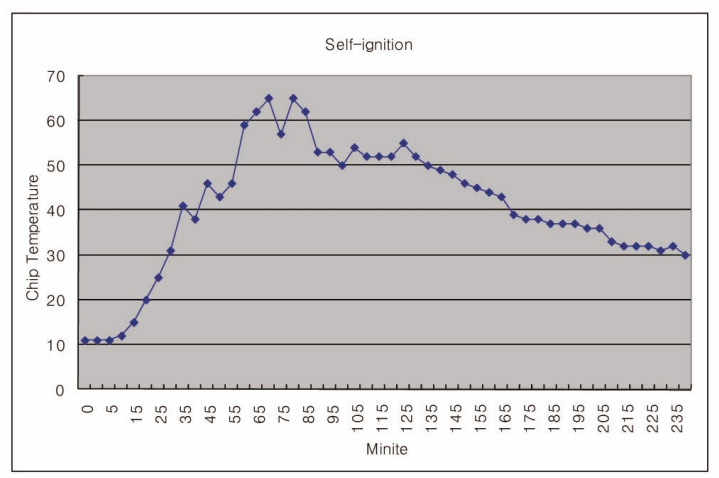

Fig. 2. Self-ignition Test after Drying Sludge-like Uranium Chips for 6.5 Hours at $300^{\circ} \mathrm{C}$ under Vacuum

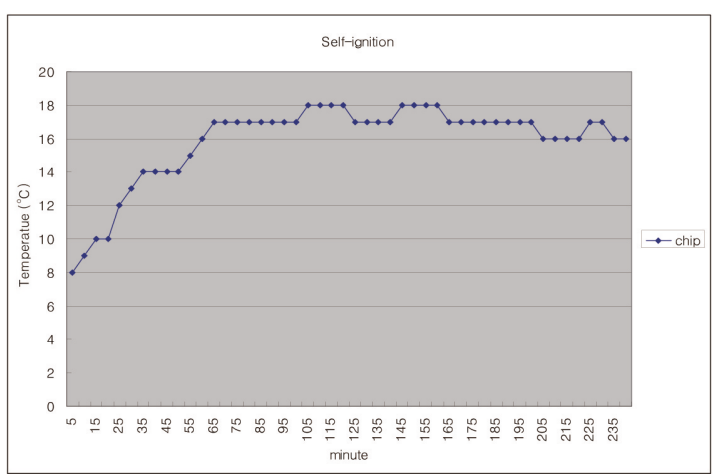

Fig. 3. Self-ignition Test after Oxidation for 7 Hours under Oxygen Atmosphere at $300{ }^{\circ} \mathrm{C}$ 


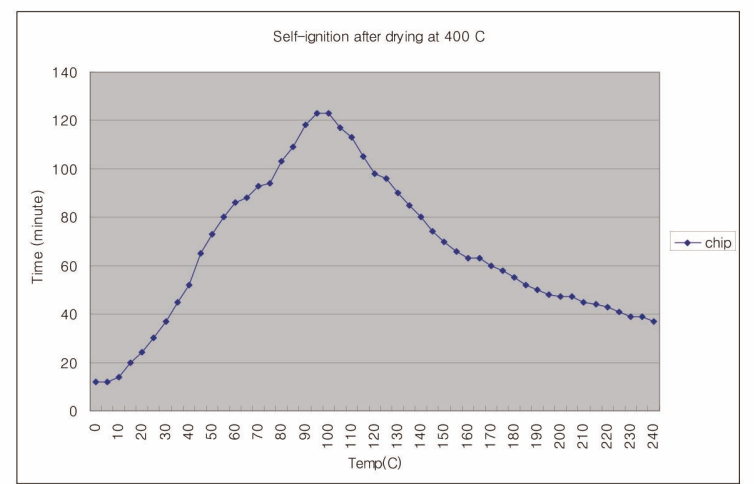

Fig. 4. Self-ignition Test after Drying for 7 Hours under Vacuum Atmosphere at $400{ }^{\circ} \mathrm{C}$

chips showed a slight lost from $12.46 \mathrm{~kg}$ to $12.36 \mathrm{~kg}$. The portion of the lost weight for the initial weight is very small at $0.38 \%$. The weight loss portion for drying and oxidizing was $20.6 \%$.

After a self-ignition test for the chip had been done for the $1^{\text {st }}$ oxidation treatment, the chip was additionally oxidized at $300{ }^{\circ} \mathrm{C}$ for about 7 hours. As above, a selfignition test was conducted in the same way. The temperature of the $\mathrm{U}$ chips increased to $34{ }^{\circ} \mathrm{C}$ over 60 minutes. The weight of the oxidized product was measured to be $12.24 \mathrm{~kg}$. The additional loss by the $2^{\text {nd }}$ oxidation treatment versus the initial input weight was $0.77 \%$.

\subsection{Oxidation at $400^{\circ} \mathrm{C}$}

Uranium chips of $15.32 \mathrm{~kg}$ were taken for an oxidation experiment at $400{ }^{\circ} \mathrm{C}$. It took about 1.0 hours to elevate the temperature up to $400{ }^{\circ} \mathrm{C}$. In order to remove the water from the sludge-like chips, they were held for 7 hours at $400{ }^{\circ} \mathrm{C}$ while evacuating the chamber by a vacuum pump. The inside pressure was maintained at 30 40 torr. On self-ignition test, the temperature rose from $12{ }^{\circ} \mathrm{C}$ to $123^{\circ} \mathrm{C}$ gradually over 95 minutes as shown in Fig. 4.

The weight of the uranium chip decreased from 15.32 $\mathrm{kg}$ to $10.8 \mathrm{~kg}$, which is $70.5 \%$ for the initial loading weight of the chip. The loss portion is corresponded to $29.5 \%$, which is bigger than the loss portion of $20.2 \%$ for drying at $300{ }^{\circ} \mathrm{C}$.

After a self-ignition test, the chips were heated to 400 ${ }^{\circ} \mathrm{C}$ for one hour in an oxygen atmosphere of about 600 torr and the oxidation condition maintained for 7 hours. A self-ignition test showed that the temperature increased from $11^{\circ} \mathrm{C}$ to $71{ }^{\circ} \mathrm{C}$ over about one hour. The temperature increase of $60{ }^{\circ} \mathrm{C}$ in the self-ignition test after the chips were firstly oxidized is much less than that of the chips that were only dried. The loss portion of the $1^{\text {st }}$ oxidation at $400{ }^{\circ} \mathrm{C}$ was $0.72 \%$ of the initially loaded U chip. It is a

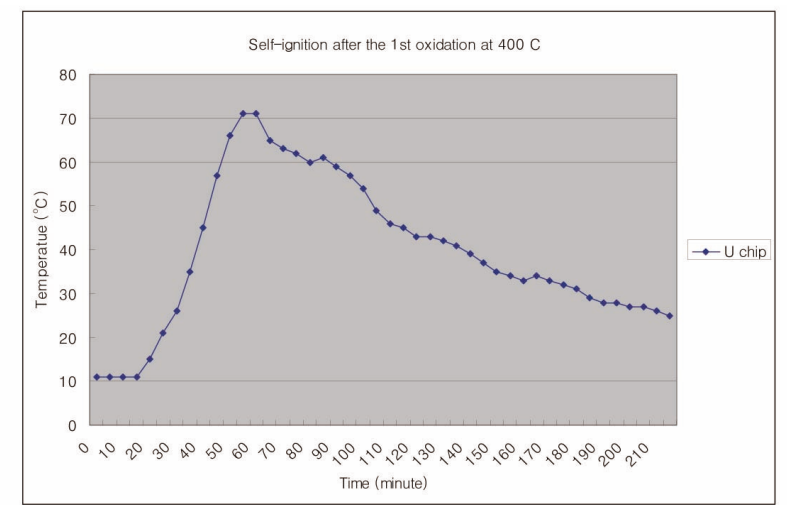

Fig. 5. Self-ignition Test after Oxidation for 7 Hours at $400{ }^{\circ} \mathrm{C}$

little more than that of the $1^{\text {st }}$ oxidized $U$ chips at $300{ }^{\circ} \mathrm{C}$. The total weight loss for drying and the $1^{\text {st }}$ oxidation treatment at $400{ }^{\circ} \mathrm{C}$ was $30.2 \%$, which is much greater than that for $300^{\circ} \mathrm{C}$.

After a self-ignition test for the chips done for the $1^{\text {st }}$ oxidation treatment, the chips were additionally oxidized at $400{ }^{\circ} \mathrm{C}$ for about 7 hours. As above, a self-ignition test was conducted in the same way. The temperature of the $\mathrm{U}$ chips increased from $13{ }^{\circ} \mathrm{C}$ to $20^{\circ} \mathrm{C}$ over 45 minutes. The additional loss by the $2^{\text {nd }}$ oxidation treatment for the initial input weight was $0.71 \%$. The total weight loss portion for the initially loaded chips regarding the whole treatment at $400{ }^{\circ} \mathrm{C}$ was about $30.9 \%$, which is greater than 21.3 for the whole treatment at $300^{\circ} \mathrm{C}$. It is assumed that the volatile materials in the chips would be more efficiently removed by increasing the temperature from $300{ }^{\circ} \mathrm{C}$ to $400{ }^{\circ} \mathrm{C}$.

\subsection{Oxidation at $500^{\circ} \mathrm{C}$}

Uranium chips of $14.01 \mathrm{~kg}$ were loaded in an oxidation chamber for an oxidation experiment at $500{ }^{\circ} \mathrm{C}$. In order to remove the water from the sludge-like chips the chips were heated up to $500{ }^{\circ} \mathrm{C}$ for about 1.0 hour and held for 7 hours at $400{ }^{\circ} \mathrm{C}$ while evacuating the chamber by a vacuum pump. The vacuum degree of the inside pressure was formed at the relatively higher pressure of $220 \sim 240$ torr a while after the temperature had risen up to $500{ }^{\circ} \mathrm{C}$. It is thought to be due to strong evaporation from the higher temperature. After that, the pressure decreased gradually to 60 torr after 2 hours had passed.

On a self-ignition test, the temperature increased from $11^{\circ} \mathrm{C}$ to $98^{\circ} \mathrm{C}$ gradually over about 100 minutes as shown in Fig. 6. When comparing with the chips dried at $400{ }^{\circ} \mathrm{C}$, the peak temperature of the self-ignition test for the chips at $500{ }^{\circ} \mathrm{C}$ was lower than that at $400{ }^{\circ} \mathrm{C}$. However the temperature of the chips decreased more slowly. The 


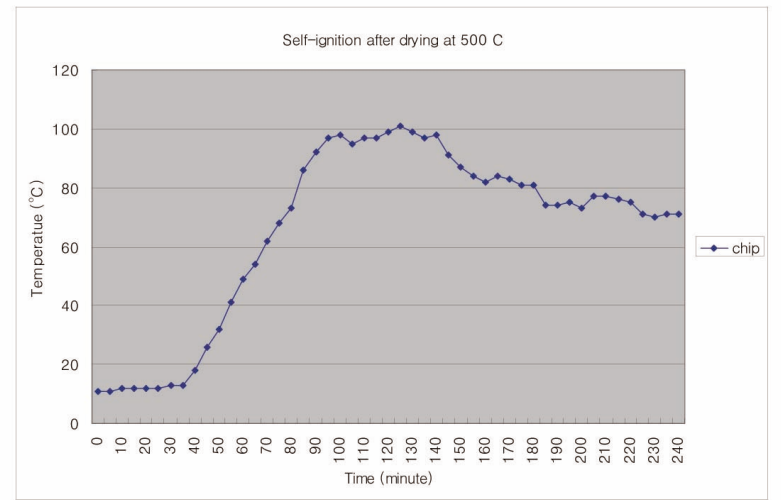

Fig. 6. Self-ignition Test after Drying for 7 Hours under Vacuum Atmosphere at $500^{\circ} \mathrm{C}$

chip weight loss after drying in the $500{ }^{\circ} \mathrm{C}$ self-ignition test was measured to be $3.72 \mathrm{~kg}$, which is $26.6 \%$ of initial loading. The loss portion for $500{ }^{\circ} \mathrm{C}$ is a little less than that for $400{ }^{\circ} \mathrm{C}$.

After a self-ignition test, the chips were heated to 500 ${ }^{\circ} \mathrm{C}$ for one hour in an oxygen atmosphere of about 600 torr and the oxidation condition was maintained for 7 hours. A self-ignition test showed that the temperature had not changed. The weight loss portion of the $1^{\text {st }}$ oxidation at $500{ }^{\circ} \mathrm{C}$ was $1.8 \%$ for the initially loaded $\mathrm{U}$ chips. The total weight loss portion was $28.3 \%$, which is less than that for $400{ }^{\circ} \mathrm{C}$. The $2^{\text {nd }}$ oxidation treatment and a selfignition test were done in the above way. There was no temperature change on the self-ignition test. In the case of $500{ }^{\circ} \mathrm{C}$, it is thought that one oxidation treatment could be sufficient. The weight loss in the 2nd oxidation treatment was almost negligible at $0.03 \mathrm{~kg}$, which is $0.2 \%$ of the initial loaded chip weight. The total weight loss portion for the initial loading was $28.6 \%$. Even though the oxidation for the $\mathrm{U}$ chip at $500{ }^{\circ} \mathrm{C}$ is more efficient than that at $400{ }^{\circ} \mathrm{C}$, the weight loss portion appeared to be smaller. Presumably this result can be attributed to the different water content of the sludge-like chips.

\section{ANALYSIS}

\subsection{Chemical Analysis}

Table 1 is the result of a chemical analysis of $U$ and $\mathrm{C}$ for various treated samples. The carbon contents of samples treated at a temperature above $400{ }^{\circ} \mathrm{C}$ are shown to be very low at less than $1.0 \mathrm{wt} \%$. However the carbon contents of samples (\#3, \#4) treated around $300{ }^{\circ} \mathrm{C}$ were shown to be large at more than $8.0 \mathrm{wt} \%$. Comparing the carbon content of sample \#4 with sample \#3, the results are almost the same, even though sample \#4 was treated 7
Table 1. Chemical Analysis of $U$ and $C$ for Various Treatments

\begin{tabular}{c|c|c}
\hline Treatments & $\mathrm{U}(\%)$ & $\mathrm{C}(\%)$ \\
\hline$\# 1$ (dried at vacuum, $100^{\circ} \mathrm{C}$ for 7 hours) & - & - \\
\hline$\#$ 2 (dried at vacuum, $300^{\circ} \mathrm{C}$ for 7 hours) & - & - \\
\hline$\#$ 3 (treated with oxygen, $300^{\circ} \mathrm{C}$ for 7 hours) & 47.9 & 8.9 \\
\hline$\# 4$ (treated with oxygen, $300^{\circ} \mathrm{C}$ for 14 hours) & 67.8 & 8.5 \\
\hline \#5 (dried at vacuum, $400^{\circ} \mathrm{C}$ for 7 hours) & 72.0 & 1.5 \\
\hline \#6 (treated with oxygen, $400^{\circ} \mathrm{C}$ for 7 hours) & 73.4 & 0.8 \\
\hline \#7 (treated with oxygen, $400^{\circ} \mathrm{C}$ for 14 hours) & 71.4 & 0.9 \\
\hline \#8 (dried at vacuum, $500^{\circ} \mathrm{C}$ for 7 hours) & 75.3 & 0.8 \\
\hline \#9 (treated with oxygen, $500^{\circ} \mathrm{C}$ for 7 hours) & 76.1 & 0.4 \\
\hline \#10 (treated with oxygen, $500^{\circ} \mathrm{C}$ for 14 hours) & 78.3 & 0.3 \\
\hline
\end{tabular}

* The samples \#1, \#2 were excluded in the analysis because the samples contained too much water due to insufficient drying.

hours longer than sample $\# 3$ at $300{ }^{\circ} \mathrm{C}$ The carbon content of the samples at $400{ }^{\circ} \mathrm{C}$ was dramatically reduced to about $1 \mathrm{wt} \%$. When the temperature increased from 400 ${ }^{\circ} \mathrm{C}$ to $500{ }^{\circ} \mathrm{C}$, the carbon content of the samples decreased further to about half value. It is thought that temperature is an important factor for removing organic materials and the temperature should be no lower than $400{ }^{\circ} \mathrm{C}$ to remove most organic material in the sample. For both temperatures of $400{ }^{\circ} \mathrm{C}$ and $500{ }^{\circ} \mathrm{C}$ the carbon content of the dried samples decreased by half through oxidation treatment for 7 hours. However, an additional oxidation treatment of the above samples for 7 hours showed little carbon reduction for both temperatures. From the above results, it is thought that 7 hours for the oxidation should be enough.

The uranium content of samples appeared to increase adversely with respect to a decrease of carbon. The very low uranium content of $47.9 \%$ in sample \#3 seems to come from insufficient drying due to a low temperature and short drying time. In general, the uranium content in the samples was shown to increase with the temperature, $67.8 \%$ at $300{ }^{\circ} \mathrm{C}, 71.4-73.4 \mathrm{wt} \%$ at $400{ }^{\circ} \mathrm{C}$, and $75.3-78.3 \mathrm{wt} \%$ at $500{ }^{\circ} \mathrm{C}$ The remaining residue after oxidation treatment at $300{ }^{\circ} \mathrm{C}$ and $400{ }^{\circ} \mathrm{C}$ was observed to be black. In the oxidation treatment at $500{ }^{\circ} \mathrm{C}$ the residue was shown to be a little yellowish. The allowable oxidation condition from a viewpoint of automatic ignition and firing is considered to be drying for 7 hours at $400{ }^{\circ} \mathrm{C}$ and oxidizing for longer than 7 hours at $400{ }^{\circ} \mathrm{C}$, which corresponds to treatment \#7. 


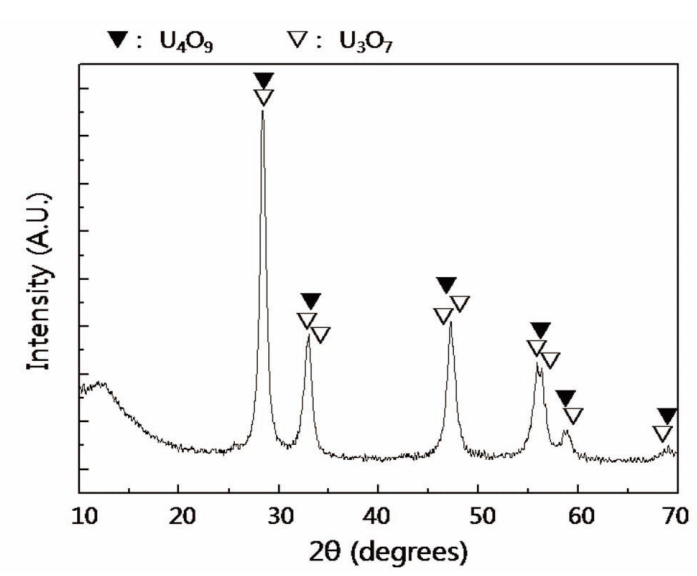

Fig. 7. XRD Patterns of Sample \#7 Treated with Oxygen, at $400{ }^{\circ} \mathrm{C}$ for 14 hours

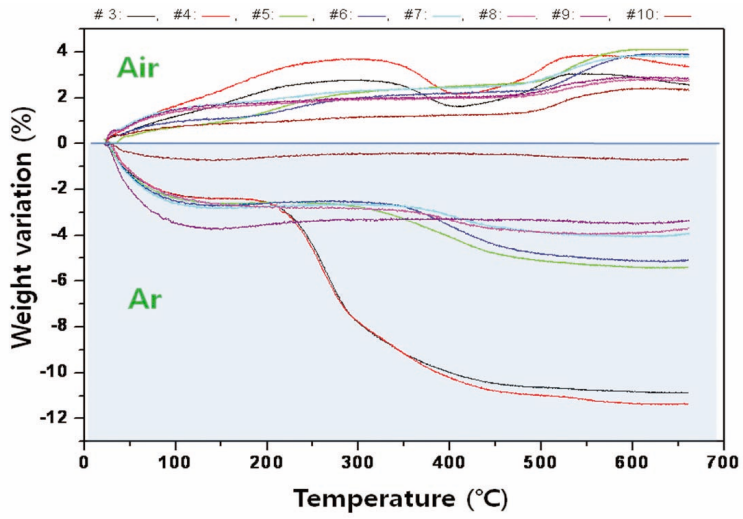

Fig. 8. Measurement of Weight Variation by Consecutive Heating, First in Ar and Second in Air, of the Oxidation Treated Samples ( \#3 - \#10)
Fig. 7 is the result of an XRD analysis for sample \#7. Sample \#7 was found to be mixed phases of $\mathrm{U}_{4} \mathrm{O}_{9}$ and $\mathrm{U}_{3} \mathrm{O}_{7}$ from the XRD patterns which are chemically stable in air.

\subsection{Thermal Gravimetric Analysis (TGA)}

Thermal gravimetric analysis on the oxidation treated samples (\#3 - \#10) were performed by consecutive heating, first in argon atmosphere and second in air, and the results are shown in Fig. 8.

The weight losses in the TGA curves from the first heating in argon atmosphere are thought to be caused by only volatile materials like water and organic materials except uranium components, because uranium components in the samples should be metal or oxide forms which are stable in argon atmosphere without further oxidation. So the weight variation curves from first the heating in argon atmosphere give an information about the amounts of organic materials retained in the oxidation treated samples. The weight losses for the samples \#3 and \#4 were large compared to those of the other samples. And the weight losses decreased little by little for the samples from \#5 to \#10 and the weight loss of sample \#10 is almost negligible. This gravimetric analysis results are in accord with the results of the chemical analysis as shown in Table 1. It is confirmed again that the oxidation treatment conditions of \# 3 and \#4 are insufficient and the oxidation treatment condition of \#10 is enough to remove almost all organic materials.

The weight variation curves from the first heating in argon show plateaus above $450^{\circ} \mathrm{C}$ regardless of oxidation treated samples. It means that the samples would attain a state without further volatilization or decomposition at a temperature near $450{ }^{\circ} \mathrm{C}$. From this result, it can be thought that the optimum treatment temperature for entire removal of organic materials of uranium metal chip samples would be near $450{ }^{\circ} \mathrm{C}$

The weight gains in TGA curves for the consecutive heating in air after heating in argon are thought to be presumably due to oxidation of the remaining $\mathrm{U}$ metal or uranium oxides with low valence.

The weight losses shown at the temperature range, $350{ }^{\circ} \mathrm{C}$ to $400{ }^{\circ} \mathrm{C}$ of the curves for the \#3, \#4 would be caused by decomposition of some materials in the air which were still retained even in the preceding heating in argon. The weight variation curves of the second heating in air show plateaus above $500{ }^{\circ} \mathrm{C}$ It means that all the samples could be converted to chemically stable $\mathrm{U}_{3} \mathrm{O}_{8}$ form near $500{ }^{\circ} \mathrm{C}$ in air. And so the oxidation condition of near $500{ }^{\circ} \mathrm{C}$ should be enough to obtain the stability from self-ignition and firing.

Two final state weights, $\mathrm{W}_{\mathrm{B}}$ and $\mathrm{W}_{\mathrm{A}}$, by heating up to $650{ }^{\circ} \mathrm{C}$ in argon and air, which are from thermal gravimetric analysis, are included in Table 2. Assuming that final product heating up to $650{ }^{\circ} \mathrm{C}$ in air is $\mathrm{U}_{3} \mathrm{O}_{8}$ form, the average oxidation states $\left(\mathrm{UO}_{\mathrm{x}}\right)$ of $\mathrm{U}$ in the oxidation treated samples (\#5 - \#10) can be calculated using two final state sample weights. The calculation for \#3, \#4 is excluded, because the $\mathrm{W}_{\mathrm{B}}$ 's for the \#3, \#4 would still include volatile materials other than uranium materials. In Table 2, the values of $\mathrm{x}$ of $\mathrm{UO}_{\mathrm{x}}$ in Table 2 have a tendency to increase with treatment temperature and time, which generally gives higher stability with respect to oxidation.

\subsection{Analysis Results by Infrared Spectra for Oxidized Samples}

The results of Infrared spectra for sample \#4 are shown in Fig. 9. The spectra for the initial state show peaks in the $2800-3000 \mathrm{~cm}^{-1}$ region, but in contrast the peaks were 
Table 2. Weight Loss and Again by Heating to $650^{\circ} \mathrm{C}$ in Argon and Air and Calculation of Average Oxidation States of Uranium in Oxidation Treated Samples

\begin{tabular}{|c|c|c|c|c|c|c|}
\hline & \multicolumn{3}{|c|}{ Argon } & \multicolumn{2}{|r|}{ Air } & \multirow{2}{*}{$\begin{array}{l}\text { Calculated average oxidation } \\
\text { states of uranium }\end{array}$} \\
\hline & $\mathrm{W}_{\mathrm{A}}^{*}(\mathrm{mg})$ & $\mathrm{W}_{\mathrm{B}}^{* * *}(\mathrm{mg})$ & $\left(\mathrm{W}_{\mathrm{B}}-\mathrm{W}_{\mathrm{A}}\right) / \mathrm{W}_{\mathrm{A}} \times 100(\%)$ & $\mathrm{W}_{\mathrm{C}}^{* * * *}(\mathrm{mg})$ & $\left(\mathrm{W}_{\mathrm{C}}-\mathrm{W}_{\mathrm{B}}\right) / \mathrm{W}_{\mathrm{B}} \times 100(\%)$ & \\
\hline$\# 3$ & 26.3 & 23.8 & -9.43 & 24.3 & 2.06 & - \\
\hline$\# 4$ & 22.1 & 20.1 & -8.97 & 20.6 & 2.34 & - \\
\hline$\# 5$ & 27.7 & 26.8 & -3.29 & 27.7 & 3.55 & $\mathrm{UO}_{2.10}$ \\
\hline \#6 & 21.3 & 20.7 & -2.68 & 21.3 & 2.89 & $\mathrm{UO}_{2.17}$ \\
\hline$\# 7$ & 17.6 & 17.5 & -0.96 & 17.9 & 2.29 & $\mathrm{UO}_{2.28}$ \\
\hline \#8 & 16.1 & 15.8 & -1.86 & 16.2 & 2.15 & $\mathrm{UO}_{2.24}$ \\
\hline$\# 9$ & 14.4 & 14.4 & 0 & 14.6 & 1.60 & $\mathrm{UO}_{2.43}$ \\
\hline$\# 10$ & 19.7 & 19.7 & -0.1 & 20.0 & 1.88 & $\mathrm{UO}_{2.41}$ \\
\hline
\end{tabular}

$\mathrm{W}_{\mathrm{A}}{ }^{*}$ : Initial weight of the samples

$\mathrm{W}_{\mathrm{B}}{ }^{* * *}$ : Final weight of the samples after heating to $650{ }^{\circ} \mathrm{C}$ in argon atmosphere

$\mathrm{W}_{\mathrm{C}}{ }^{* * *}$ : Final weight of the samples after heating to $650^{\circ} \mathrm{C}$ in air atmosphere

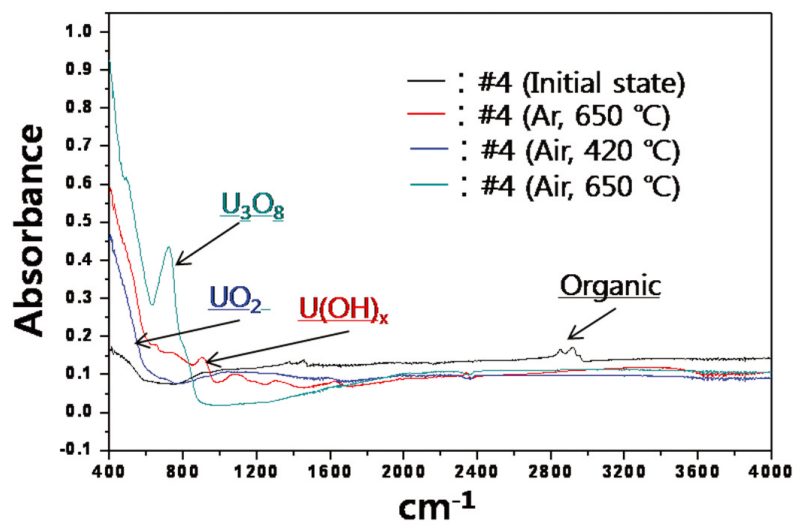

Fig. 9. Characterization of Species by IR Spectra after Consecutive Heating of the Sample \#4 in thE Order of, 1) Ar, $650{ }^{\circ} \mathrm{C}, 2$ ) Air, $420^{\circ} \mathrm{C}, 3$ ) Air, $650{ }^{\circ} \mathrm{C}$

absent in the spectra for the sample which was heated at $650^{\circ} \mathrm{C}$ in Ar. From this absence of peaks, it can be deduced that the peaks are attributed to organic compounds which can evaporate by heating at $650{ }^{\circ} \mathrm{C}$ in Ar. The peaks in the region $850-1600 \mathrm{~cm}^{-1}$ for the sample heated at $650{ }^{\circ} \mathrm{C}$ in $\mathrm{Ar}$ are not easy to identify, but they are thought to be caused by uranium hydroxide compounds $[\mathrm{U}(\mathrm{OH}) \mathrm{x}][6]$, since peaks of uranium oxides (UOx) in this region have not been found in the literature and the samples have been stored in water for a long time.

The spectra for the sample heated at $420{ }^{\circ} \mathrm{C}$ in air shows a typical feature of uranium dioxides $\left(\mathrm{UO}_{2+\mathrm{x}}\right)$ but in contrast it does not show the peaks in the 850-1600 $\mathrm{cm}^{-1}$ region. The spectra for the sample heated at $650{ }^{\circ} \mathrm{C}$ in air shows a peak of $715 \mathrm{~cm}^{-1}$, which is a typical $\mathrm{U}_{3} \mathrm{O}_{8}$ peak.

\section{CONCLUSION}

The self-ignition test using the new oxidation treatment process showed the results of temperature rise, of $60^{\circ} \mathrm{C}$ for 7 hours oxidation, of $7{ }^{\circ} \mathrm{C}$ for 14 hours oxidation at $400{ }^{\circ} \mathrm{C}$ and no temperature rise for 7 hours oxidation at $500{ }^{\circ} \mathrm{C}$. From these temperature rise results, the condition of the oxidation treatment for 7 hours at $500{ }^{\circ} \mathrm{C}$ is thought to be enough as a condition for safe storage of uranium chips.

The carbon content results by chemical analysis show that organic materials of uranium chips were removed to a few $\%$ by oxidation treatments at $400{ }^{\circ} \mathrm{C}$ and removed further to tiny amount by oxidation treatments at $500{ }^{\circ} \mathrm{C}$. And, according to the thermal gravimetric analysis, the optimum temperature for entire removal of organic materials of uranium metal chip samples was known to be near $450{ }^{\circ} \mathrm{C}$

From the IR spectra, X-ray deflection measurements and the thermal gravimetric analysis, it is known that the major phases of uranium of uranium chip samples are $\mathrm{U}_{4} \mathrm{O}_{9}$ and $\mathrm{U}_{3} \mathrm{O}_{7}$ when treated at $400{ }^{\circ} \mathrm{C}$ and $\mathrm{U}_{3} \mathrm{O}_{8}$ when treated at the temperature higher than $500{ }^{\circ} \mathrm{C}$, which are chemically stable in air. 
Accordingly the optimum condition for the oxidation treatment for $\mathrm{U}$ metal chips stored under water are concluded to be at the temperature, near $500{ }^{\circ} \mathrm{C}$ and the duration longer than 7 hours.

\section{REFERENCES}

[1] Charles W. Solbrig et al. "Pyrophoricity of Uranium in Long-term Storage Environments", Argonne National Laboratory

[2] In-Hyung Moon, "Powder Metallurgy", 1981, p49

[3] "A Study on the Oxidation Behavior of Uranium",
KAERI/TR-987/98, Korea Atomic energy Research Institute

[4] "Assessment of enrichment Uranium Storage Safety Issues at the Oak Ridge Y-12 Plant" Y/014/R4, 1996, Oak Ridge Y-12 Plant

[5] "Primer on Spontaneous Heating and Pyrophoricity", DOE Handbook, “DOE-HDBK-1081-94”, 1994, Dec.

[6] "Statement of Work, Treatment and disposal of uranium and thorium chips at various department of energy sites", Nov. 8, 2001

[7] V. Baran, L. Sourkova, J. Spalova, J. Radioanal. Nucl. Chem., Letters 95 (1985) 331-338 